\title{
The Relationship between Trade Openness, Foreign Direct Investment and Economic Growth in West Africa: Static Panel Data Model
}

\author{
John Wiredu, Emmanuel Nketiah*, Mavis Adjei \\ School of Business, Nanjing University of Information Science \& Technology, Nanjing, China \\ Email: *nketia888@hotmail.com
}

How to cite this paper: Wiredu, J., Nketiah, E., \& Adjei, M. (2020). The Relationship between Trade Openness, Foreign Direct Investment and Economic Growth in West Africa: Static Panel Data Model. Journal of Human Resource and Sustainability Studies, 8, 18-34.

https://doi.org/10.4236/jhrss.2020.81002

Received: December 26, 2019

Accepted: February 23, 2020

Published: February 26, 2020

Copyright $\odot 2020$ by author(s) and Scientific Research Publishing Inc. This work is licensed under the Creative Commons Attribution International License (CC BY 4.0).

http://creativecommons.org/licenses/by/4.0/

(c) (i) Open Access

\begin{abstract}
This study investigates empirically the relationship between Trade openness (OPEN) and Foreign Direct Investment (FDI) on the economic growth for a panel of four (4) West African countries (Côte d'Ivoire, Ghana, Nigeria, and Senegal) during the period of 1998 to 2017. The static panel regression techniques were employed to assess the causal link of our regressors, namely, FDI, trade openness, investment and Inflation to economic growth measured by Gross Domestic Product (GDP). Levin-Lin-Chu unit-root test was conducted to find the stationarity of the panel data. The evidence from the statistical analysis suggests that aggregated trade openness, investment, and inflation do have a positive and significant impact on economic growth and is thus consistent with the literature, especially for developing countries. Based on static random effects, the addition of the foreign direct investment (FDI) did not deviate from the results, notwithstanding its negative impact on economic growth. The contribution of trade openness, investment and inflation are observed to be relatively higher than foreign direct investment.
\end{abstract}

\section{Keywords}

Foreign Direct Investment, Trade Openness, Economic Growth, West Africa

\section{Introduction}

Foreign direct investment (FDI) and international trade have normally been seen as channel enabling economic growth and integration of transition countries with the world economy. Foreign Direct Investment (FDI) is generally defined by an investment made in an economy by a foreign investor in the form of 
either establishing overseas business operations or acquiring assets, which gives them ownership or controlling interest. It plays a crucial role in promoting economic activity as it is a primary source of capital and technology transfer into the economy. Foreign Direct Investment (FDI) and trade openness are measured as a key element of economic growth in the developing and least developed countries (LCDs) (Alfaro \& Chanda, 2006; Pegkas, 2015; Hussain \& Haque, 2016). Economic growth is the increase in the value of goods and services produced in an economy over time, traditionally measured as gross domestic product (GDP) or real GDP per capita to adjust nominal GDP to inflation and eliminate its' distorting effect on prices of output. Foreign direct investment (FDI) is the main way to transfer technology from developed countries to developing countries. FDI also inspires domestic investment and facilitates improvements in human capital and institutions in the host countries (Omisakin et al., 2009).

Openness to trade aids the transfer of technology and knowledge into the economy, which contributes to exploitation of comparative advantage through increasing exposure to competition. Adu-Gyamfi et al. (2020) stated that trade Openness has a significant negative impact on GDP using the pooled OLS and an insignificant impact using the fixed and Random effects tests. Frankel and Romer (1999) stated that international trade is also identified to be an instrument of economic growth. International trade permits more efficient production of goods and services by which production is shifting to countries that have a comparative advantage in producing them.

The role of FDI and trade openness has been widely recognized as the considerable mechanisms of economic growth. Many past studies show that FDI and trade have a positive impact on economic growth (Baharom et al., 2008; Sabir et al., 2019). The size of such impact may vary across countries depending on the level of human capital, domestic investment, infrastructure, macroeconomic stability, and trade policies. The literature continues to debate the role of FDI and trade in economic growth as well as the importance of economic and institutional developments in fostering FDI and trade Baharom et al. (2008). This lack of consensus limits our understanding of the role of FDI and trade strategies in economic growth and limits our ability to develop strategies to promote economic growth. Barlow (2006) discovered that the level of trade is found to raise the growth rate, mainly in the early part of the evolution and for the countries nearest to the European Union. In particular, Makki \& Somwaru (2004); Farshid et al. (2009); Serge \& Yue (2010); Bhattacharya (2010); Adhikary (2012) and Belloumi (2014) concluded that inflow foreign direct investment and trade openness promotes the economic growth of the host countries.

The persistence of this study is to explore and appraise the effect of FDI and trade openness on economic growth within framework in West Africa. FDI inflows and trade openness and their respective influence on economic growth is important, given its significance in explaining economic growth in the Omisakin et al. (2009) West African countries (Côte d'Ivoire, Ghana, Nigeria, and Senegal) under study and other developing economies in West Africa. Since the start of 
economic deliverance policies in West Africa in the 1980s, the volume of trade and FDI inflows has been on the rise which tends to affect the economic growth of West African countries positively and negatively completely in the 4 countries under the study.

The following Figure 1 shows the growth trend of FDI, export, and import as a percentage of GDP from the four (4) West Africa countries for the period of 1998-2017. From Figure 1, 1 represent Côte d'Ivoire, 2 represent Ghana, 3 represent Nigeria, and 4 represent Senegal. In Figure 1, it is demonstrated that FDI inflows in Nigeria were very low. However, it rises between the year 2005-2010 and decreased thereafter from 2010-2017. Ghana experienced similar FDI trends as Nigeria in the beginning but had a significant rise of FDI between the periods 2005 to 2007 compared to Nigeria's. It fells severely from 2008 and kept experiencing rises and falls till 2017. However, it was greater than Nigeria's in those latter periods under study. Côte d'Ivoire from the beginning period of the study has a higher FDI compared to both Nigeria and Ghana. Between the periods where Ghana and Nigeria were experiencing growth, they seem to be experiencing a fall. Their fall was however consistent until 2015 (2006 to 2015). The best-performing country among the four as far as FDI is concerned is Senegal. As can be seen in (a), it has the highest FDI throughout the year's understudy amidst its significant rises and falls. Similarly, the rate of growth of export shows an increasing trend in the initial years. Ghana had the worst between the periods of 2001 to 2007 but started to rise again from 2009 to 2012. Nigeria experienced various rises and falls between the same periods. Senegal comparatively has the lowest export. But notwithstanding the sharp fall from 2001 to 2002, it performed very well with rising export from 2002 to 2012. Côte d'Ivoire had the highest export throughout the periods. It exports had an overall increase between 2002 and 2011. During the latter part of the years under study, as can be seen in (c), all four countries experienced an overall decrease in exports (2011 to 2017). In that scenario, Nigeria was however overtaken by Senegal who has been at the bottom since inception. Ghana also overtook Côte d'Ivoire at the latest part of the study period (2016). Diagram (b) gives an illustrative detail of to 2010 but was overtaken by Senegal in 2010. Nigeria had the lowest import imports

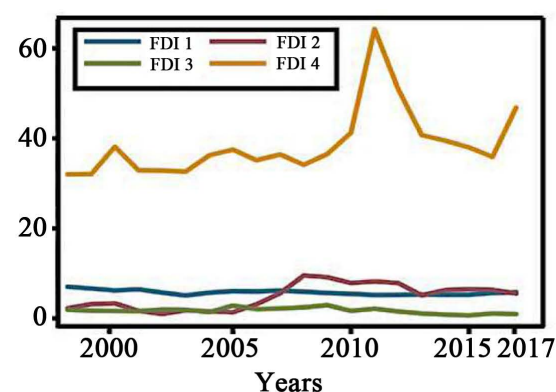

(a)

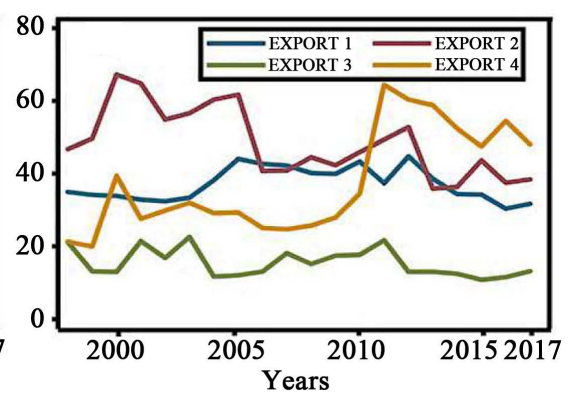

(b)

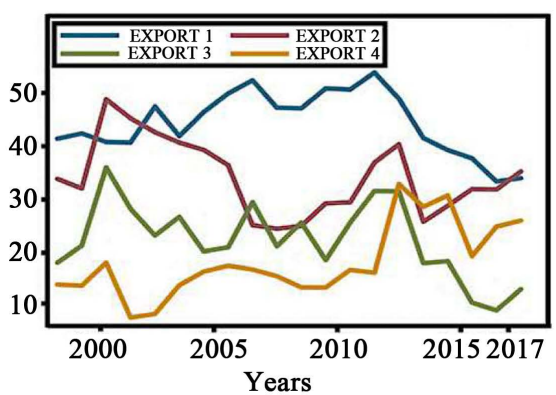

(c)

Figure 1. Reflects the growing trend of FDI, export, and import as a percentage of GDP from the four (4) West Africa countries (Côte d'Ivoire, Ghana, Nigeria, and Senegal) for the period of 1998-2017. Source: The World Bank database. 
for these countries as well. Ghana had the highest import rate from 1997 throughout the periods under study notwithstanding the numerous rises and falls.

Figure 2 below reflects the annual percentage growth rate of GDP from the four (4) West African countries for the period between 1998-2017. Ghana had the lowest GDP growth rate in the initial period 1998-2010 then Côte d'Ivoire took over from 2010-2013 and Senegal came in from 2013-2017. It also shows that Nigeria had the highest GDP growth rate among these four (4) West Africa countries between 2004-2017 after some competitive struggles with Côte d'Ivoire and Senegal who were initially on top between 1998 and 2004. Ghana after taking over Senegal and Côte d'Ivoire kept performing very well until it overtook Nigeria who has been at the top from inception at the latter part.

With economic growth, Nigeria has become one of the fastest-growing economies within these (4) West African countries. About this, many argue that FDI and trade (export plus import), inter alia, play a significant role in achieving growth and development. As FDI and trade represent the most important variables in explaining growth dynamics, understanding the causal connections between these phenomena is important for developing strategies for the four (4) West African countries and other developing countries in Africa. Therefore, this study is guided by the following specific research objectives:

* To estimate the unit root test of all the variables in the study by using the Levin-Lin-Chu unit-root test in the four (4) countries in West Africa.

* To examine the causal interrelationship among FDI, trade openness and economic growth in four (4) West Africa countries.

* To estimate the relationship and dynamics of FDI, trade openness and economic growth in four (4) West Africa countries using the recent econometric technique.

The study is systematized as follows:

The prior element which talks about the background of the study is Section 1. Section 2 reviews various kinds of literature related to the study with a brief overview of FDI, domestic investment and economic growth. Section 3 reveals the data source and methodology for the study. Section 4 deals with Results,

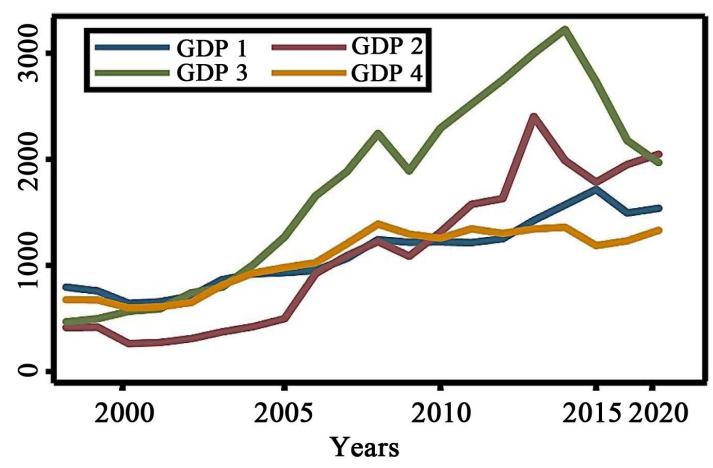

Figure 2. Reflects the annual percentage growth rate of GDP from the four (4) West Africa countries (Côte d'Ivoire, Ghana, Nigeria, and Senegal) for the period 1998-2017. Source: The World Bank database. 
discussion, and analysis of the study whiles the last Section concludes the study with recommendations

\section{Literature Review}

Trade openness is a vigorous component that pays to economic performance. Largely, the trade potential of a country is signified by the GDP level in the country which fascinates foreign investment, thus fashioning extra more trade opportunities. Openness to trade supports the transfer of technology and knowledge into the economy and donates to the exploitation of comparative advantage through rising exposure to competition. Therefore, it can be claimed that there is a positive link between openness and economic growth, based on sound theoretical grounds.

Over the previous years, there have been various strands of empirical and theoretical analyses meant at investigating the relationship between macroeconomic indicators including FDI and openness to trade. Farshid et al. (2009) estimated Utilizing the Augmented Production Function (APF) growth model to analyze the impact of FDI and trade openness on economic growth in designated countries such as Korea, China, Philippine, Thailand, and Malaysia. The panel data designed from 1980-2006 for each country were analysis by the panel data approach. The result of this study demonstrates that there exists a cointegration relationship between and its determinant in the APF model. The study found that there is a positive impact of inflow foreign direct investment and trade openness on economic growth only in the case of Thailand, Korea, and China. A study indicated that international trade advocates that, trade contributes positively to the long-term growth prospects of a country (Van den Berg \& Lewer 2015).

Sakyi et al (2015) investigates the long-run impact of foreign direct investment and trade openness on economic growth in Ghana (1970-2011) within the framework of the endogenous growth literature. The study adopted the autoregressive distributed lag bounds testing approach to cointegration the results suggest that the interaction of foreign direct investment and exports has been crucial in fostering growth.

Makki and Somwaru (2004) were applied the panel data of 66 developing countries over three years on the impact of foreign direct investment and trade openness on economic growth. The study estimates a system of three equations, where dependent variables are the growth rate of GDP per capita and domestic investment. Temporarily, the independent variables are FDI, inflation rate, trade openness, government consumption, and human capital. The study confirms that foreign direct investment relates positively to the trade to stimulate economic growth and domestic investment in developing countries.

Adhikary (2012) had studied the impact of foreign direct investment, domestic demand, foreign exchange rate, and trade openness on the export performance of Bangladesh by employing the vector error correction model (VECM) and time series from the period 1980-2009. The study checks the stationary of 
both intercept and intercept plus the trend of ADF and PP approaches were exploited to investigate for stationarity of variables. The study engaged a Vector Error Correction Model (VECM). The empirical study indicates that FDI is positively related to export performance in the long-run and short-run, but not for the other variables.

The empirical study by Hussain \& Haque (2016) using the time series data from 1973-2014. The study shows a positive effect of foreign direct investment, trade openness and economic growth in Bangladesh. Adegboyega and Odusanya (2014) study reveal a significant positive effect between the degree of trade openness, level of the capital formation while a positive but insignificant relationship between the volume of FDI and gross domestic product growth rate.

Dutta et al. (2017) scrutinized the causal relationship between trade openness, foreign direct investment, domestic investment and economic growth over the period 1976-2014. The research found unidirectional causality running from foreign direct investment to growth, domestic investment to trade openness, economic growth to trade openness and bidirectional causality among domestic investment and economic growth and foreign direct investment and domestic investment. Ved and Sudesh (2007) examined the relationship between trade openness and economic growth in the case of India and found bidirectional causality among economic growth and trade openness indicators. Acaravc and Öztürk (2012) the results show both short-term and long-term casualties between FDI, export, and growth in four of the ten countries. Fetahi-Vehapi et al. (2015) estimate the Generalized Method of Moments (GMM) estimator on panel datasets, Southeast European (SEE) countries from the year 1996-2012. The study found positive effects of trade openness on economic growth are conditioned by the initial income per capita and other explanatory variables. Else, there is not robust evidence between these two variables. Moreover, the trade openness is more beneficial to countries with a higher level of initial income per capita, as well as trade openness favors countries with a higher level of FDI and with higher gross fixed capital formation. Mahmoodi and Mahmoodi (2016) established Panel-VECM causality: Eight European developing countries 1992-2013 and eight Asian developing countries, 1986-2013. The causality results of eight European countries indicated bidirectional causality between economic growth and FDI, and unidirectional causality from economic growth and FDI to exports in the short-term. The empirical results of the Asian countries indicated bi-directional causality between exports and economic growth in the short-term. Moreover, there is evidence of long-run causality from export and FDI to economic growth and long-run causality from economic growth and export to FDI for both of the panels.

Several studies have attempted to explore the interrelationship between FDI, trade openness and economic growth and the evidence has been mixed (Asghar \& Hussain, 2014; Hye \& Lau, 2015; Szkorupová, 2014). Thus, the literature shows that the results of the FDI inflows and trade openness impact on economic growth have been quite varied and inconclusive. Several studies have at- 
tempted to explore the negative relationship between FDI, trade openness and economic growth. Bakari and Tiba (2019) paper examine the impact of trade openness, domestic investment, and foreign investment inflows on economic growth for the case of 24 Asian economies over the period 2002-2017. The study used fixed and random effect models. The investigation found that foreign direct investment and exports are negatively affecting the growth path. Belloumi (2014) estimates ARDL from the year 1970-2008 in Tunisia. The study indicated that there is no significant Granger causality from economic growth to FDI, from FDI to economic growth, from economic growth to trade and from trade to economic growth in the short run. Meanwhile, there is a prevalent belief that FDI can create positive spillover externalities for the host country, the empirical study results failed to approve that FDI could create positive spillover externalities for the host country. Naveed and Shabbir (2006) used a fixed effect and control set of variables, Granger Causality, 23 developed countries from the year 1971-2000. The study establishes that there is strong unidirectional causality from trade openness to economic growth, but foreign direct investment (FDI) does not have an impact on growth. Hye and Lau (2015) examined the link between trade openness and economic growth in India. The research indicates a negative and unbalanced effect of trade openness on economic growth through the sample in the long run. Farshid et al. (2009) indicated that foreign direct investment and trade openness have a negative relationship on economic growth in the case of the Philippine and Malaysia.

The diverse views on the nexus between the variables show a literature gap, allowing us to develop more interest to further discover the relationship between FDI, trade openness and economic growth where few studies have been conducted. Precisely, not many studies have been attempted to recognize the relationship between FDI, trade and economic growth in the context of four (4) West Africa countries (Côte d'Ivoire, Ghana, Nigeria, and Senegal). Therefore, the paper contributes to the existing literature using recent data and the relationship between the above variables in multivariate form by examining the four (4) West Africa countries (Côte d'Ivoire, Ghana, Nigeria, and Senegal).

\section{Data and Methodology}

\subsection{Data Collection}

The use of panel data on 4 West Africa countries (Côte d'Ivoire, Ghana, Nigeria, and Senegal) for the period 2004-2018 are extracted from the World Development Indicators (WDI) and World Governance Indicators (WGI) from the World Bank database. The data set on the variables, FDI and trade openness (TOP) are sourced from World Development Indicators WDI (2019). Following Mensah et al. (2019) and Nketiah et al. (2020), the dependent variable in this model is real GDP growth (annual \%) as a proxy of economic growth. The independent variables include FDI measured as the net inflow of foreign direct investment as a share of GDP and trade measured as total trade as a share of GDP. 
The variable trade openness is proxied by export plus import as a percentage of GDP, economic growth is proxied by GDP and FDI is Inward FDI (net inflows) as a \% of GDP. Inflation (INFLA) is measured as GDP deflator (annual \%). It is the increase in the prices of goods and services over time. Inflation reduces the purchasing power of each unit of currency. Investment is a measure of Gross fixed capital formation (annual \% growth). All datasets are in the annual percentage (\%).

The descriptive statistics which include the means, standard deviations, minimum and maximum values of variables are shown below. Table 1 presents the results of the variables used in the study. The results show that the average GDP growth is 1245.172, recording a minimum of 263.113 and a maximum of 3221.678. Trade openness had a mean value of 65.835 with a minimum value of 20.723 and a maximum of 116.048. Inflation has a mean percentage of 29.978 with a minimum percent of 0.686 and a maximum of 80.755 . FDI has a mean percentage of 4.294 with a minimum percent of 0.634 and a maximum of 9.517 . The last variable that is investment has an average mean of 19.911 with a minimum of 8.254 and a maximum of 40.553 .

\subsection{Regression Model}

The model specification follows the growth function where the level of economic performance is conjectured to be sensitive to foreign capital and trade flows in the presence of strong institutional quality (Flora \& Agrawal, 2017). Based on previous empirical literature and data availability, three econometric models will be considered. OLS, Fixed effect, and random effect model. Hausman's test will be used to determine the most suitable model for the research. The three models are explained below.

\subsubsection{Pooled Ordinary Least Square (OLS) Regression}

Pooled OLS can be used to derive unbiased and consistent estimates of parameters even when time constant attributes are present. In short, Pooled regression is just another way of saying that you are assuming no id or time fixed effects.

The ordinary linear econometric model that will be used in this study is as follows:

$$
y_{1}=\beta_{0}+\beta_{1} x_{i t}+\beta_{2} x_{i t}+\cdots+\beta_{n} x_{i t}+\mu_{i t}
$$

Table 1. Descriptive analysis test results.

\begin{tabular}{cccccc}
\hline Variable & Observations & Mean & Standard deviation & Minimum & Maximum \\
\hline GDP GROWTH & 80 & 1245.172 & 662.544 & 263.113 & 3221.678 \\
INFLATION & 80 & 29.978 & 16.621 & 0.686 & 80.755 \\
FDI & 80 & 4.294 & 2.127 & 0.634 & 9.517 \\
OPEN & 80 & 65.835 & 21.246 & 20.723 & 116.048 \\
INVESTMENT & 80 & 19.911 & 6.824 & 8.254 & 40.553 \\
\hline
\end{tabular}


The study used the foreign direct investment, trade openness and economic growth in four (4) West African countries focusing on developing a simple economic growth model for the countries as shown below:

$$
\mathrm{GDP}_{i t}=\beta_{o}+\beta_{1} \mathrm{FDI}_{i t}+\beta_{2} \mathrm{INFLA}_{i t}+\beta_{3} \mathrm{TOP}_{i t}+\cdots+u_{i t}
$$

where:

GDP $=$ Gross Domestic Product Growth (annual \%) at time $t$

FDI $=$ Inward FDI (net inflows) as a $\%$ of GDP at time $t$,

INFLA = Inflation is measured as GDP deflator (annual \%).

TOP $=$ Trade openness as a $\%$ of GDP, i.e. (Imports + Exports) as a $\%$ of GDP at time $t$,

The subscripts $\mathrm{i}$ and $\mathrm{t}$ represent countries and periods respectively.

\subsubsection{Fixed Effect Model}

Fixed effects (FE) is used whenever you are only interested in analyzing the impact of variables that vary over time. It explores the relationship between predictor and outcome variables within an entity (country, person, company, etc.). FE removes the effect of those time-invariant characteristics so we can assess the net effect of the predictors on the outcome variable. The equation for the fixed effects model becomes:

$$
Y_{i t}=\beta_{1} X_{i t}+a_{i}+\mu_{i t}
$$

where

$a_{i}(i=1, \cdots, n)$ is the unknown intercept for each entity (n entity-specific intercepts).

$Y_{i t}$ is the dependent variable (DV) where $i=$ entity and $t=$ time?

$X_{i t}$ represents one independent variable (IV),

$\beta_{1}$ is the coefficient for that IV?

$\mu_{i t}$ is the error term

$$
\mathrm{GDP}_{i t}=\alpha_{i}+\beta_{1} \mathrm{FDI}_{i t}+\beta_{2} \mathrm{INFLA}_{i t}+\beta_{3} \mathrm{TOP}_{i t}+\cdots+u_{i t}
$$

where;

GDP $=$ Gross Domestic Product Growth (annual \%) at time $t$,

FDI $=$ Inward FDI (net inflows) as a $\%$ of GDP at time $t$,

INFLA = Inflation is measured as GDP deflator (annual \%),

TOP $=$ Trade openness as a \% of GDP, i.e. (Imports + Exports) as a \% of GDP at time $t$.

\subsubsection{Random Effects Model}

The rationale behind the random effects model is that, unlike the fixed effects model, the variation across entities is assumed to be random and uncorrelated with the predictor or independent variables included in the model. An advantage of random effects is that you can include time-invariant variables (i.e. gender). In the fixed effects model these variables are absorbed by the intercept. The random effects model is:

$$
Y_{i t}=\beta_{1} X_{i t}+a_{i}+\mu_{i t}+\varepsilon_{i t}
$$


where:

$a_{i}(i=1, \cdots, n)$ is the unknown intercept for each entity ( $n$ entity-specific intercepts).

$Y_{i t}$ is the dependent variable (DV) where $i=$ entity and $t=$ time?

$X_{i t}$ represents one independent variable (IV),

$\beta_{1}$ is the coefficient for that IV?

$\mu_{i t}$ is the Between-entity error

$\varepsilon_{i t}$ is the within-entity error

$$
\mathrm{GDP}_{i t}=\alpha_{i}+\beta_{1} \mathrm{FDI}_{i t}+\beta_{2} \mathrm{INFLA}_{i t}+\beta_{3} \mathrm{TOP}_{i t}+\cdots+u_{i t}+\varepsilon_{i t}
$$

where:

GDP $=$ Gross Domestic Product Growth (annual \%) at time $t$,

FDI $=$ Inward FDI (net inflows) as a $\%$ of GDP at time $t$,

INFLA = Inflation is measured as GDP deflator (annual \%),

TOP $=$ Trade openness as a $\%$ of GDP, i.e. (Imports + Exports) as a \% of GDP at time $t$.

Random effects assume that the entity's error term is not correlated with the predictors which allow for time-invariant variables to play a role as explanatory variables.

\section{Results and Analysis}

\section{Unit Root Test}

The unit root test accomplishes a variety of tests for the stationarity (or unit roots) in panel datasets. All these tests have as the null hypothesis that all the panels contain stationarity (Levin, Lin, \& Chu, 2002; Breitung, 2000; Harris \& Tzavalis, 1999; Breitung \& Das, 2005; Choi, 2001; Im, Pesaran, \& Shin, 2003). The output of the topmost for each test creates explicit null and alternative hypotheses. Preferences permit you to involve panel-specific means (fixed effects) and time trends in the data-generating process model (Table 2).

The test adopts that all panels have an identical autoregressive parameter, which is rho_i $=$ rho for all I (Levin, Lin, \& Chu, 2002). Formerly the alternative hypothesis is pure that rho $<1$. The Levin-Lin-Chu test obliges that the panel data balanced strongly. The Levin-Lin-Chu test is built on a regression $t$ statistic because the data are nonstationary under the null hypothesis, the asymptotic mean and standard deviation of the $t$ statistic be contingent on the specification of the deterministic part of the model.

Table 2 established the Unit root test of the estimation to test for the stationarity of the variables. The Levin-Lin-Chu unit-root test was used to estimate the result. The logarithm of variables was not all test stationary. The variable inflation and investment were test stationery at logarithm, but the other variables did not stationary. Based on the first difference, all the variables were tested stational, which indicates that all the variables were stationary at first difference.

Table 3 showed the regression coefficients for the model estimating the impact of selected factors on economics growth using Panel data. From the Table, the model shows that Investment, Trade Openness (TOP) and inflation were 
significant at $5 \%$ level in pooled OLS estimation. FDI recorded an insignificant at $5 \%$ level of $28 \%$. This suggests that Investment, inflation and TOP are good explanatory variables for determinants of Economic growth in the four West African countries. The coefficient on the explanatory variables is negative except FDI and constant variable (C) (Table 3).

Based on the tests conducted, we can observe that under the static fixed effect regression, Inflation share a negative coefficient and insignificant at 5\% level whiles FDI inflows share a positive coefficient and also insignificant at 5\% level. Investment and Trade Openness (TOP) both have a significant effect at $5 \%$ level with a positive (44.113) and negative (-23.11) impact on GDP growth respectively.

This suggests that INFLATION and OPEN are good explanatory variables for determinants of Economic growth (GDP GROWTH) in the four West African countries except for FDI. The coefficients of the explanatory variables are negative (except FDI) (Table 4).

Under the Random Effects model (see Table 1), shows that all the variables GDP GROWTH, FDI, INFLA \& TOP). This model portrays similar behavior as pooled OLS with parameter estimates of 0.006 for inflation demonstrating a negative and significant relationship at 5 percent. This implies that for every

Table 2. Levin-lin-chu unit-root test.

\begin{tabular}{ccc}
\hline Variables & LOG & First Differences \\
\hline GDP GROWTH & 0.2088 & 0.0002 \\
FDI & 0.0809 & 0.0000 \\
INFLATION & 0.0062 & 0.0000 \\
OPEN & 0.3526 & 0.0000 \\
INVESTMENT & 0.0050 & 0.0000 \\
\hline
\end{tabular}

Note: Ho: Panels contain unit roots, Ha: Panels are stationary.

Table 3. Pooled OLS regression test results.

\begin{tabular}{ccccc}
\hline GDP GROWTH & Coefficient & Standard Error & t-statistic & $P$-value $(P<0.05)$ \\
\hline C & 3408.878 & 307.716 & 11.08 & $0.000^{*}$ \\
INFLATION & -11.009 & 4.030 & -2.73 & $0.008^{*}$ \\
FDI & 34.643 & 31.809 & 1.09 & 0.280 \\
OPEN & -17.203 & 3.090 & -5.57 & $0.000^{*}$ \\
INVESTMENT & -42.683 & 9.019 & -4.73 & $0.000^{*}$ \\
Adjusted R-squared & & 0.446 & \\
R-squared & & 0.474 \\
F-statistic & & 16.91 & \\
Prob (F-statistic) & & 0.0000 \\
No of observations & & 80 & \\
\hline
\end{tabular}


Table 4. Fixed effect (FE) test results.

\begin{tabular}{ccccc}
\hline GDP GROWTH & Coefficient & Standard Error & t-statistic & $P$-value $(P<0.05)$ \\
\hline C & 3733.426 & 580.067 & 6.44 & $0.000^{*}$ \\
INFLATION & -6.271 & 42.370 & -0.99 & 0.327 \\
FDI & 23.164 & 46.255 & 0.55 & 0.586 \\
OPEN & -23.110 & 5.643 & -4.10 & $0.000^{*}$ \\
INVESTMENT & 44.113 & 10.600 & -4.16 & $0.000^{*}$ \\
R-squared & & 0.4031 & \\
Prob > F & & 0.0000 & \\
Number of observations & & 80 & \\
Number of groups & & 4 \\
\hline
\end{tabular}

percentage increase in inflation, GDP growth will decrease by 0.006 percent. FDI has a positive coefficient (34.643) but insignificant at 5\% level. Trade Openness has a positive and statistically significant relationship with at 5 percent with GDP growth. From the RE regression, it is reported to have a coefficient estimate of 17.203 percent which indicates a slightly positive impact on economic growth. Investment also has a statistically significant and positive contribution to GDP growth. This suggests that all the variables are good explanatory variables for determining Economic Growth in the four West African countries except FDI. The coefficients of the explanatory variables are positive except inflation (Table 5).

Hausman test for the Exogeneity of the Unobserved Error Component

If the unobserved effects are exogenous, the FE and RE are asymptotically equivalent. This suggests the null hypothesis for the Hausman test:

$$
H_{o}: \hat{\beta}_{R E}=\hat{\beta}_{F E}
$$

where $\hat{\beta}_{R E}$ and $\hat{\beta}_{F E}$ are coefficient vectors for the time-varying explanatory variables, excluding the time variables.

Table 5. Random effect (RE) test results.

\begin{tabular}{ccccc}
\hline GDP GROWTH & Coefficient & Standard Error & t-statistic & $P$-value $(P<0.05)$ \\
\hline C & 3408.878 & 307.716 & 11.08 & $0.000^{*}$ \\
INFLATION & -11.009 & 4.030 & -2.73 & $0.006^{*}$ \\
FDI & 34.643 & 31.809 & 1.09 & 0.276 \\
OPEN & 17.203 & 3.090 & -5.57 & $0.000^{*}$ \\
INVESTMENT & 42.683 & 9.019 & -4.73 & $0.000^{*}$ \\
R-squared & & 0.3881 & \\
Prob $>$ chi2 & & 0.0000 & \\
Number of observations & & 80 & \\
Number of groups & & 4 \\
\hline
\end{tabular}


Table 6. Hausman test results.

\begin{tabular}{ccccc}
\hline \multirow{2}{*}{ Variables } & \multicolumn{4}{c}{ Coefficients } \\
\cline { 2 - 5 } & (b) & $(\mathrm{B})$ & $(\mathrm{b}-\mathrm{B})$ & $\mathrm{sqrt}\left(\operatorname{diag}\left(\mathrm{V}_{-} \mathrm{b}-\mathrm{V} \_\mathrm{B}\right)\right)$ \\
\cline { 2 - 5 } & $\mathrm{fe}$ & $\mathrm{Re}$ & Difference & S.E. \\
\hline INFLATION & -6.271 & -11.009 & 4.738 & 4.916 \\
FDI & 23.164 & 34.643 & -11.479 & 27.990 \\
OPEN & -23.110 & -17.203 & -5.906 & 4.722 \\
INVESTMENT & -44.113 & -42.683 & -1.430 & 5.570 \\
chi2(4) & & & 4.43 & \\
Prob $>$ chi2 & & & 0.3505 & \\
\hline
\end{tabular}

If the null hypothesis is rejected, we conclude that RE is inconsistent, and the FE model is preferred.

If the null hypothesis cannot be rejected, random effects are preferred because it is a more efficient estimator.

The $X^{2}$ statistic is positive and also greater than $5 \%$ which shows strong evidence that we can accept the null hypothesis and concluded that random effects estimator is appropriate for the model. This implies that the random effect model is the appropriate model (Table 6).

\section{Conclusion and Recommendation}

\subsection{Conclusion}

This study examines the relationship of trade openness, FDI and economic growth for selected four (4) West African countries (Ghana, Nigeria, Côte d'Ivoire, and Senegal) during the period of 1998-2017. The selection was based on data availability, including the most important economies and all the major sectors in the 4 West African countries. The evidence from the statistical analysis using the Random Effects model suggests that aggregated OPEN, inflation and Investment does have a positive and significant relationship on economic growth and is thus consistent with the literature, especially to developing countries. Based on static random effects, the addition of foreign direct investment (FDI) did not deviate the results notwithstanding its negative impact on economic growth. The contribution of trade openness, inflation and investment is perceived to be relatively higher than FDI. It is most likely that a foreign firm that decides to enter the local market through Investment enjoys lower costs and higher production efficiency than its domestic competitors. Trade openness size is seen to contribute significantly and positively to economic growth. Based on random effect, we find out that trade openness, inflation, and investment have positive relationships and significant impact on economic growth and only FDI does not have a significant impact on economic growth.

Based on the test for cross-sectional dependence correlation by using the $\mathrm{Pa}$ saran CD test, we found out that, $\mathrm{P}$-value is less than $5 \%$ which simply means the Null hypothesis is rejected but accepts the alternate hypothesis. The study 
concluded that there is a cross-sectional dependence in the model. The test for heteroskedasticity also concluded that there is heteroskedasticity in the model. The serial correlation concluded that there is a serial correlation in the model.

The Levin-Lin-Chu unit-root test was used to estimate the Stationarity of the data. The outcomes of the logarithm of variables were not all test stationary. The variable inflation and investment were test stationery at logarithm, but the other variables indicate a sign of Stationarity. Based on the first difference, all the variables were tested stational, which indicates that all the variables were stationary at first difference.

\subsection{Recommendation}

Trade openness, inflation, and investment demonstrate a significant positive rise in economic growth. They have played a significant role in the economic development of Côte d'Ivoire, Ghana, Nigeria, and Senegal economies by creating job opportunities, transferring technology and know-how and at the same time motivated the local private sector to improve their performance in the competition. More diversification is necessary to increase the level of FDI inflows to become more sustainable in the future. Statistical shreds of evidence from FE and RE tests show that foreign direct investment has a negative significant impact on economic growth. Policymakers can set up and improve political strategies and corporate tax policies by reviewing tax structures and investing in local productions, both on small and large scales. Export diversification policies can be positively associated with economic growth. The political dominance of multinational companies is still far too strong. Governments of the major emitting countries should place a stringent price policy on emissions of greenhouse gases by taxing them, instead of effectively subsidizing them. Policymakers should promote green technology which is now the trending tool to unlock Côte d'Ivoire, Ghana, Nigeria, and Senegal economic and energy potential. This will not only help to eradicate poverty, build a more productive labor force and meet the economic needs of Côte d'Ivoire, Ghana, Nigeria, and Senegal poorest countries and people, but it will also help in contributing to international cooperation and enhance growth and economic development. Hence, the above results highlight the economic importance of trade openness, inflation, and investment and provide new shreds of evidence for the case of West African economies.

\section{Acknowledgements}

We spread our special thankfulness to the developers, managers and funding agencies of World Bank Development indicators (WDI) for granting access to these essential datasets in accordance to their specific data use and citation policies.

\section{Conflicts of Interest}

The authors declare no conflicts of interest regarding the publication of this paper. 


\section{References}

Acaravc, A., \& Öztürk I. (2012). Foreign Direct Investment, Export and Economic Growth: Empirical Evidence from EU Countries. Romanian Journal of Economic Forecasting, 2, 52-67.

Adegboyega, S. B., \& Odusanya, I. A. (2014). Empirical Analysis of Trade Openness, Capital Formation, Foreign Direct Investment and Economic Growth: Nigerian Experience. The International Journal of Social Sciences and Humanities Invention, 1, 36-50.

Adhikary, B. K. (2012). Impact of Foreign Direct Investment, Trade Openness, Domestic Demand, and Exchange Rate on the Export Performance of Bangladesh: A VEC Approach. Economics Research International, 2012, Article ID: 463856. https://doi.org/10.1155/2012/463856

Adu-Gyamfi, G., Nketiah, E., Obuobi, B., \& Adjei, M. (2020). Trade Openness, Inflation and GDP Growth: Panel Data Evidence from Nine (9) West Africa Countries. Open Journal of Business and Management, 8, 314-328. https://doi.org/10.4236/ojbm.2020.81019

Alfaro, L., \& Chanda, A. (2006). How Does Foreign Direct Investment Promote Economic Growth? Exploring the Effects of Financial Markets on Linkages. National Bureau of Economic Research Working Paper Series, No. 12522(2), 242-256. https://doi.org/10.3386/w12522

Asghar, N., \& Hussain, Z. (2014). Financial Development, Trade Openness and Economic Growth in Developing Countries: Recent Evidence from Panel Data. Pakistan Economic and Social Review, 52, 99-126.

Baharom, A. H., Habibullah, M. S., \& Royfaizal, R. C. (2008). The Relationship between Trade Openness, Foreign Direct Investment and Growth: Case of Malaysia (pp. 1-10).

Bakari, S., \& Tiba, S. (2019). The Impact of Trade Openness, Foreign Direct Investment and Domestic Investment on Economic Growth: New Evidence from Asian Developing Countries. The Economic Research Guardian, 9, 46-54.

Barlow, D. (2006). Growth in Transition Economies: A Trade Policy Perspective. Economics of Transition, 14, 505-514. https://doi.org/10.1111/j.1468-0351.2006.00264.x

Belloumi, M. (2014). The Relationship between Trade, FDI and Economic Growth in Tunisia: An Application of the Autoregressive Distributed Lag Model. Economic Systems, 38, 269-287. https://doi.org/10.1016/j.ecosys.2013.09.002

Bhattacharya, M. (2010). Causal Nexus Between Trade, FDI and Economic Growth-Evidence from India. Paradigm, 14, 12-23.

https://doi.org/10.1177/0971890720100104

Breitung, J. (2000) The Local Power of Some Unit Root Tests for Panel Data. Advances in Econometrics, 15, 161-177. https://doi.org/10.1016/S0731-9053(00)15006-6

Breitung, J., \& Das, S. (2005). Panel Unit Root Tests under Cross-Sectional Dependence. Statistica Neerlandica, 59, 414-433. https://doi.org/10.1111/j.1467-9574.2005.00299.x

Choi, I. (2001). Unit Root Tests for Panel Data. Journal of International Money and Finance, 20, 249-272. https://doi.org/10.1016/S0261-5606(00)00048-6

Dutta, C. B., Haider, M. Z., \& Das, D. K. (2017). Dynamics of Economic Growth, Investment, and Trade Openness: Evidence from Bangladesh. South Asian Journal of Macroeconomics and Public Finance, 6, 82-104. https://doi.org/10.1177/2277978717695150

Farshid, P., Ali, S., \& Gholamhosein, S. (2009). The Impact of Foreign Direct Investment and Trade on Economic Growth-Taking China, Korea, Malaysia, Philippines \& 
Thailand for Example. China-USA Business Review, 8, 37-43.

Fetahi-Vehapi, M., Sadiku, L., \& Petkovski, M. (2015). Empirical Analysis of the Effects of Trade Openness on Economic Growth: An Evidence for South East European Countries. Procedia Economics and Finance, 19, 17-26. https://doi.org/10.1016/S2212-5671(15)00004-0

Flora, P., \& Agrawal, G. (2017). FDI and Economic Growth Nexus for the Largest FDI Recipients in Asian Emerging Economies: A Panel Co-Integration Analysis. In: International Business Strategy (pp. 261-275). London: Palgrave Macmillan. https://doi.org/10.1057/978-1-137-54468-1_12

Frankel, J. A., \& Romer, D. (1999). Does Trade Cause Growth? American Economic Review, 89, 379-399. https://doi.org/10.1257/aer.89.3.379

Harris, R. D. F., \& Tzavalis, E. (1999). Inference for Unit Roots in Dynamic Panels Where the Time Dimension Is Fixed. Journal of Econometrics, 91, 201-226. https://doi.org/10.1016/S0304-4076(98)00076-1

Hussain, M. E., \& Haque, M. (2016). Foreign Direct Investment, Trade, and Economic Growth: An Empirical Analysis of Bangladesh. Economies, 4, 7. https://doi.org/10.3390/economies4020007

Hye, Q. M. A., \& Lau, W. (2015). Trade Openness and Economic Growth: Empirical Evidence from India. Journal of Business Economics and Management, 16, 188-205. https://doi.org/10.3846/16111699.2012.720587

Im, K. S., Pesaran, M. H., \& Shin, Y. (2003). Testing for Unit Roots in Heterogeneous Panels. Journal of Econometrics, 115, 53-74. https://doi.org/10.1016/S0304-4076(03)00092-7

Levin, A., Lin, C.-F., \& Chu, C.-S. J. (2002). Unit Root Tests in Panel Data: Asymptotic and Finite-Sample Properties. Journal of Econometrics, 108, 1-24. https://doi.org/10.1016/S0304-4076(01)00098-7

Mahmoodi, M., \& Mahmoodi, E. (2016). Foreign Direct Investment, Exports and Economic Growth: Evidence from Two Panels of Developing Countries. Economic Research-Ekonomska Istraživanja, 29, 938-949. https://doi.org/10.1080/1331677X.2016.1164922

Makki S. S., \& Somwaru, A. (2004). Impact of Foreign Direct Investment and Trade on Economic Growth: Evidence from Developing Countries. American Journal of Agricultural Economics, 86, 795-801. https://doi.org/10.1111/j.0002-9092.2004.00627.x

Mensah, E. K, Asamoah, L. A., \& Bondzie, E. A. (2019). Trade Openness, FDI and Economic Growth in Sub-Saharan Africa: Do Institutions Matter? Transnational Corporations Review, 11, 65-79. https://doi.org/10.1080/19186444.2019.1578156

Naveed, A., \& Shabbir, G. (2006). Trade Openness, FDI and Economic Growth: A Panel Study. Pakistan Economic and Social Review, 44, 137-154.

Nketiah, E., Cai, X., Adjei, M., \& Boamah, B. B. (2020). Foreign Direct Investment, Trade Openness and Economic Growth: Evidence from Ghana. Open Journal of Business and Management, 8, 39-55. https://doi.org/10.4236/ojbm.2020.81003

Omisakin, O., Adeniyi, O., \& Omojolaibi, A. (2009). Foreign Direct Investment, Trade Openness and Growth in Nigeria. Journal of Economic Theory, 3, 13-18.

Pegkas, P. (2015). The Impact of FDI on Economic Growth in Eurozone Countries. Journal of Economic Asymmetries, 12, 124-132. https://doi.org/10.1016/j.jeca.2015.05.001

Sabir, S., Rafique, A., \& Abbas, K. (2019). Institutions and FDI: Evidence from Developed and Developing Countries. Financial Innovation, 5, Article No. 8.

https://doi.org/10.1186/s40854-019-0123-7 
Sakyi, D., Commodore, R., \& Opoku, E. E. O. (2015). Foreign Direct Investment, Trade Openness and Economic Growth in Ghana: An Empirical Investigation. Journal of African Business, 16, 1-15. https://doi.org/10.1080/15228916.2015.1061283

Serge, C., \& Yue, Y. X. (2010). The Relationship between Foreign Direct Investment, Trade Openness and Growth in Côte d'Ivoire. International Journal of Business and Management, 5, 99-107. https://doi.org/10.5539/ijbm.v5n7p99

Szkorupová, Z. (2014). A Causal Relationship between Foreign Direct Investment, Economic Growth and Export for Slovakia. Procedia Economics and Finance, 15, 123-128. https://doi.org/10.1016/S2212-5671(14)00458-4

Van den Berg, H., \& Lewer, J. J. (2015). International Trade and Economic Growth. New York: Routledge Publishing.

Ved, P., \& Sudesh, P. (2007). An Empirical Investigation of the Causal Relationship between Openness and Economic Growth in India. Asian Economic Review, 49, 485-494.

WDI (2019). World Development Indicator. World Bank Database. https://datacatalog.worldbank.org/dataset/world-development-indicators

\author{
Abbreviations \\ GDP GROWTH: Gross Domestic Product Growth \\ FDI: Foreign Direct Investment \\ INFLA: Inflation \\ TOP: Trade Openness \\ FE: Fixed Effect \\ RE: Random Effect \\ WDI: World Development Indicators
}

